\title{
Andrew J. Counter
}

\section{A SENTIMENTAL AFFAIR: VÉRITÉ}

$\mathrm{O}^{\prime}$ n 29 November 1899, ten days after President Émile Loubet signed an instrument pardoning Alfred Dreyfus for a crime that no one now believed he had committed, Émile Zola shared with the readers of L'Aurore his own vision of the Dreyfus family's reunion. In an open letter to Lucie Dreyfus, Zola pictured the likely scene in the Dreyfus household:

Je m'imagine la première soirée, sous la lampe, dans l'intimité familiale, lorsque toutes les portes sont fermées et que toutes les abominations de la rue meurent au seuil domestique. Les deux enfants sont là, le père est revenu du lointain voyage, si long, si obscur. [.. .] Une douceur endort la maison close, une infinie bonté baigne de toutes parts la chambre discrète où sourit la famille. (18: 466)

Scenes of unalloyed familial bliss such as this one are, we might observe, in rather short supply in the fictional works for which Zola is most famous. In contradistinction to the bitterness of family life as depicted in his RougonMacquart cycle, Zola applies to this imagined family reunion an adjective that is of particular interest to me in what follows: the moment of Dreyfus's return is delicious or delightful, a "minute délicieuse." That "minute" is, moreover, "trempée de bonnes larmes"; lubricated, that is, by the unmistakable oil of nineteenth-century sentimentalism (18: 466).

"Most often, where the epithet 'sentimental' [.. .] is brought onto the scene," writes Eve Kosofsky Sedgwick, the intended meaning is "a discreditable or devalued one-the sentimental as the insincere, the manipulative, the vicarious, the morbid, the knowing, the kitschy, the arch" (143). It would take a cynical soul indeed, of course, to quarrel on such grounds with Zola's appeal to sentimental topo $i$ in this passage of his letter to Mme Dreyfus. Over and against the clear ideological freighting of such images, their indisputable involvement, then as now, with the promotion of middle-class familialism, we

The author wishes to thank Ann Jefferson, Marco Wan, Claire White, and Nick White for their helpful comments on drafts of this article. An earlier version was presented to the Modern French Research Seminar at the University of Oxford; thanks are due to the participants.

The Romanic Review Volume 102 Numbers 3-4 0 The Trustees of Columbia University 
must surely recognize the all too real mutilation inflicted on this particular family by ideologies arguably more pernicious, and accept the good faith of Zola's celebration of that family's ultimate, unlikely rehabilitation. And yet, if sentimentalism in the letter is defined by the domestic circle of the long-suffering Dreyfus family, it is nevertheless not confined to that privileged locus amoenus. On the contrary, the consoling warmth of Dreyfus's foyer in fact provides the model for a much larger form of national repentance and reconciliation:

Votre mari [. . .] a tant souffert, et sans cause, [. . .] que nous voudrions panser d'une tendresse chacune de ses plaies. Nous sentons bien que la réparation est impossible, que jamais la société ne pourra payer sa dette envers le martyr, [. . .] et c'est pourquoi nous lui élevons un autel dans nos cœurs, n'ayant à lui donner rien de plus pur ni de plus précieux que ce culte de fraternité émue. (18: 468)

While we might still be reluctant to call this passage "insincere" or "manipulative," we must at the very least agree that it is both strategic and, fundamentally, political. For a start, Zola's use of an ambiguous "nous" and the subsequent invocation of "fraternite" might well permit the uninformed reader to imagine that Żola speaks for a unanimously repentant Republic, rather than for a faction of a nation whose radical division at the time of the article's publication has become legendary. And yet it is in the coupling of that grandly universal term "fraternité" with the normally particularizing adjective "émue" - a word that, along with the earlier "tendresse," I shall take in this article as a specific textual indicator that we are in the presence of the Zolian sentimental-that Zola's rhetorical strategy becomes distinctly legible. This conjugation of a republican value with a tender affect is, I would argue, revelatory of Zola's turn-of-the-century attempt to reconceive political and civic relations in sentimental terms.

It is this sentimentalization of the political that I wish to consider here, partly through reference to Zola's Dreyfus journalism, but principally through a reading of the late novel Vérité (1903), at once a pseudoallegorical transposition of the Affair and an unabashed roman à thèse in support of state secular education. Like much of Zola's later fiction, Vérité draws heavily on a range of sentimental tropes whose apparent mawkishness is almost certainly directly proportional to the intensity of the political conviction in whose cause they are deployed. While it may well be the case that the sentimentalism of what Henri Mitterand has called le quatrième Zola accounts in no small part for the critical disfavor in which these works were held until recently, my argument here follows critics including Sedgwick and Margaret Cohen in attempting to 
think seriously rather than dismissively about the sentimental. Rather than seeing its prominence in his later work as indicating merely the decline of his powers as a novelist, I want to consider how Zola's use of sentimental tropes is in its own way innovative and provocative-though also profoundly flawed in its ideological implications and evasions, especially where sex is concerned. For sexuality is (notwithstanding a certain critical blindness in this regard) utterly central to the novel, forming, indeed, both the zenith and the nadir of potential human behavior as the novel imagines it. The despicable crime that represents Dreyfus's alleged treason is a sex crime, while the novel's utopian future is constructed around what Zola takes to be a frank, humanistic model of sexuality, supposedly one specially conducive to (if not synonymous with) human happiness. Yet as we shall see, in articulating more explicitly the erotic content that we may well consider to have silently inhered in sentimental writing since its origins in the late eighteenth century (and especially with Rousseau, whose philosophical and stylistic influence is to be felt everywhere in Vérité), Zola chooses to eliminate many of the possibilities of that eroticism in favor of a relentlessly normative, procreative heterosexuality. Central to my investigation of these eroticized, politicized sentimentalist tropes, as indeed to Zola's novel, is the figure of the child, for it is this figure-as at once the unfortunate victim of the novel's gruesome crime narrative, the potential beneficiary of educational reform, and, of course, the prized end result of heterosexual sexual relations-who emerges as the primary object of the novelist's sentimental solicitude.

\section{"Tous s'attendrirent"}

The plot of Vérité departs from the rape and murder of Zéphirin, a slightly hunchbacked yet eerily beautiful boy of around twelve or thirteen, by an unknown person. The orphaned son of a Jewish father and a Gentile mother, he has been receiving a Catholic education at the Jesuit school in the town of Maillebois, but resides with his uncle and guardian, the local state schoolteacher Simon, who is a Jew. After the boy's murder, a combination of antiSemitic prejudice, mistrust of secular education, and, of course, clerical conspiracy leads suspicion to fall on the heretofore irreproachable Simon, who is subsequently arrested, tried, and convicted of the crime. Central to the case is a certain modele d'écriture or classroom writing sampler, evidently used by Zéphirin's assailant to gag the boy and then abandoned at the scene; the modele bears an ambiguous monogram, which spurious graphological analysis determines to be Simon's. Simon is duly imprisoned, and the remainder of the novel follows the quest of another schoolteacher, Marc Froment, to clear his colleague's name and uncover the real culprit-the louche monk Frère Gorgias, one of Zéphirin's teachers at the Jesuit school. 
Marc's endeavors will, very belatedly, bear fruit; Simon is released after a decade or so of imprisonment and returns to Maillebois to take up residence in a house built for him and paid for by the repentant townspeople. As he arrives, he is welcomed by a choir of local schoolchildren in a scene of smiling childish beauty that acts as the redemptive pendant to Zéphirin's angelic corpse: "Rien ne fut plus simple ni plus émouvant, une strophe enfantine, de la gentille tendresse et un peu du souriant avenir, tout ce qu'il pouvait y avoir de délicat et de pur" (20:371). As this quotation suggests, it is in these final scenes that Zola's novel approximates most closely to the tone of the sentimental genre. In the final hundred pages, indeed, the characters' experience of sentimental feelings-their being "touched," being "moved," shedding tears-not only becomes a narrative event worthy of sustained attention but even displaces the notional "plot" as the principal narrative focus. This shift is announced and perfectly crystallized in the narrator's peculiar description, at the beginning of the novel's fourth and final book, of a moment shared by a number of fellow instituteurs, including Marc and his former mentor Salvan, who have gathered to take stock of the progress they have made: "Tous s'attendrirent, autour de la grande table de pierre" (20:316). Tous s'attendrirent: does this grammatically peculiar construction not come close to being utterly devoid of narrative and even of descriptive content? It is clear, after all, that the assembled schoolteachers are not doing anything, to themselves or to one another; yet insofar as they are feeling something, the phrase "tous s'attendrirent" does so little to specify, and still less to individuate, that feeling that it may hardly be said to resemble typical realist descriptions of character psychology. In one sense, it seems, this phrase is nothing more than a tonal marker, an indicator of the novel's mood as much as that of the subject-"tous"- to which it is notionally tied. And yet that "tous" is itself highly significant, for what will be most wearisome about the ensuing chapters is their insistence on the universality of the sentimental paroxysms ("un véritable délire de cris et de gestes," 20: $371)$ evoked. In the final reconciliation scene, in which Simon returns to Maillebois, we read how "des larmes coulaient de tous les yeux, des baisers sans fin furent échangés" (20:371) and how "tous se pressaient autour de [Simon]" and "l'embrassaient"; we hear "une dernière acclamation [. . .] dans laquelle s'unissaient tous les cœurs du peuple" (20:372).

Clearly, these ecstatic crowd scenes perform much the same work as the passage already quoted from the letter to Mme Dreyfus-that is, they suggest the phantasmatic possibility that an absolute emotional unanimity might spontaneously issue forth from an affair, Simon's or Dreyfus's, whose defining feature hitherto has been its power to divide opinion. Such a suggestion is, as I have already observed, strategic and political; it forms, indeed, the ultimate horizon of that politicization of the sentimental that has been at work since the beginning of the novel. The equivalence between shared feeling and political 
agreement is not, moreover, left ambiguous in Vérité: while the mayor of Maillebois briefly frets that "il nous faut l'unanimité dans le conseil" if the house for Simon is to be built (20:359), the narrator informs us only pages later that "le projet [...] fut voté à l'unanimité des voix" (20:362). These moments announce the ultimate normativity of Zola's political project-the convenient emergence of absolute consensus in the novel's final stages reflects the most extreme understanding of the Rousseauian "general will" and clearly implies (as that concept is often thought to) a progressive suppression of difference.

It is not, however, the Dreyfus allegory alone that demands this kind of affective resolution. Zola applies the same pattern to another particularly acrimonious debate of turn-of-the-century France, namely, that opposing universal secular schooling to Catholic educational establishments. It is no coincidence that the generalizing of tenderness found in the novel's fourth part should begin at a friendly meeting of Republican schoolteachers, for the novel is concerned throughout to imbue the activities of the Instruction Publique with all the tender charm of family life. Early on in the novel, Marc's vocation is explained in terms combining the urge to standardization and rationalization that has characterized French Republican educational policy since its inception, with a sentimental solicitude for "the little ones":

Ce don de l'enseignement, il l'avait découvert en lui, lorsque, bachelier à dix-sept ans, il était venu terminer son apprentissage de dessinateur lithographe [...] à Beaumont. Chargé de l'exécution de tableaux scolaires, il s'était ingénié à les simplifier encore, il avait créé de véritables chefs-d'œuvre de clarté et de précision, qui lui avaient indiqué sa voie, son bonheur à instruire les petits de ce monde. (20: 39-40)

This passage neatly aligns Marc's vocation with that of the didactic roman à thèse, which recognizes, in Susan Suleiman's words, "the necessity of simplifying and schematizing its representations for the sake of its demonstrative ends" (23). For Marc, whose various pedagogical qualifications are explained in otiose detail in the first chapter (20:21), the obtaining of state accreditation is less a submission to bureaucracy than a joyful process allowing the progressive realization of his innermost self, the discovery of his personal genius, and the best means of securing happiness; the passage even tries, though surely fails, to make pedagogical flowcharts a locus of pseudopaternal warmth. In this peculiar vision, moreover, "les petits de ce monde" may be imagined as Simon's choristers are, in terms ostensibly suggesting only their unique capacity to exude and generate affect, "de la gentille tendresse et un peu du souriant avenir" (20:371). Yet they may also be described in terms that make clear the Foucauldian biopolitics underpinning such images, as "la matière brute 
dont serait faite la nation future" (20:114). For Zola, it seems, there is no contradiction between these two registers; what the novel promotes, indeed, is precisely a technocratic tenderness, a sentimentalism of the state.

This convergence of the sentimental and the governmental-regulatory gaze upon the figure of the child was, however, neither new nor unique to Zola. In fact, the presentation of such a hybrid view in Vérite is largely consonant with a sentimentalized discourse of state child protection that had emerged in the early 1880 s and that posited the family "as one of the most critical sites for state action that would [. . .] build a positive, secular, and morally coherent republican society" (Schafer 10). Children, it transpired, were the state's best entrée to the private sphere (cf. Donzelot 76), and the ideological role of a sentimentalizing novel like Vérité was to establish the properly familialist credentials of this state intervention in family life, principally by reimagining the state and its agents as part of the family. In the novel's penultimate chapter, Marc, now close to retirement, visits a former pupil's home to discuss the construction of the house for Simon. The pupil receives him effusively and insists that Marc kiss his young daughter, a "fillette délicieuse" named Georgette (20:351):

-Mon trésor, tu te souviendras que monsieur Froment t'a embrassée et que tu en seras glorieuse toute ta vie.

-Oh ! je sais, maman, je vous entends bien en causer des fois.

C'est comme si un peu de soleil descendait me voir.

Et tous riaient tendrement. (20:351)

This passage, perhaps more than any other in the novel, owes its special mawkishness first to the jarring contrast between the childish ingenuousness it depicts and the extreme self-consciousness of the writing, and second and more importantly to the obviousness with which it performs its ideological work. The apotheosis of the instituteur witnessed here places a government functionary at the heart of the nuclear family as a totemic figure of sentimental adoration. Wreathed in sunlight like a secular halo, Marc appears as the purveyor not of some abstract technical knowledge but rather of beatific kisses. Yet the novel goes further, proposing this model of state-family relations as the ideal form of civic relations as well, in an orgiastic fantasy entertained by Marc as he anticipates Simon's return:

Il leur pardonnait bien volontiers à tous, [. . . ] il aurait voulu que la fête projetée, pour le retour de Simon, fût une vaste réconciliation, un baiser général où Maillebois entier redevint fraternel, travaillant désormais au seul bonheur de tous. (20:360)

As in the letter to Mme Dreyfus and its reference to "fraternité émue," Zola "re-familializes," as it were, the abstract, somewhat cold Republican virtue 
of fraternity, reimagining it in terms of the tender, affective love (supposedly) shared by biological brothers. In this vision, the latecomer third term of the Republican device supplants its older companions, monadic liberté and bureaucratic égalité, to announce a state no longer formed by the accretion of equal individuals but emerging instead organically from the loving cohesion of family life. The "baiser général" of Marc's fantasy thus marks the furthest extreme of the unanimity so prized by the novel's politics, for it represents the final dissolution of individuality into an undifferentiated affective community; yet it is also the most tellingly awkward expression of that politics, neither recognizing nor satisfactorily disavowing the potential-inevitable?-erotic overtones of the pseudoincestuous kisses it promotes. Instead, Marc's sentimental vision collapses sexual, civic, familial, and confessional identities into a single promiscuous synecdoche, eliding whatever questions and tensions might arise from each of these categories in pursuit of a chillingly illiberal pax gallica.

\section{The Politics of Sentiment}

It is in this erotic-sentimental reimagining of the political that Zola's novel, along with its companions Fécondité (1899) and Travail (1901), most closely reflects the aesthetic and political engagements of a certain sentimental fictional tradition, essentially that pioneered by George Sand in what Cohen has called her "sentimental social novels." In a now-famous letter to Octave Mirbeau of 1899 , Zola disingenuously attributed this new sentimental turn to the softening effects of age: "voici quarante ans que je dissèque, [ . . . ] il faut bien permettre à mes vieux jours de rêver un peu" (18:646). Yet few readers have been fooled by this claim, nor did Zola probably intend his correspondent to be: clearly, as Claire White puts it, "this facade of fatigue belies the author's tireless political engagement at the fin de siècle" (698), and Béatrice Laville notes that "l'utopie" as it appears in his later works "témoigne [. . . ] de la constance de l'engagement de l'écrivain" (235). In fact, the literary approach underpinning the fantasy at work in Vérité's closing scenes has much in common with the esthetico-political principle of "idealism," to use the term employed by Sand herself and developed by Naomi Schor: that principle creates, in Schor's words, "a passage between the most intimate erotic transactions and the most divisive political struggles" (99) and thus represents a new mode of engagement with, rather than a flight from, those same struggles.

White's assessment of Zola's tardy espousal of this literary politics in the novel Travail argues convincingly that both he and Sand resist the increasing privatization of sentiment in nineteenth-century France, which "witnessed the gradual dislocation of affective experience from both marketplace and workplace" (700). Yet in addition to his clearly considerable concern about the pressures occasioned by expanding industrial capitalism, Zola may well have had another reason to harness the power of sentiment in the service of a 
Sandian progressive politics, namely, the awareness that the enemies of such a politics were themselves excellent manipulators of sentimental tropes and concepts. Consider the following from a poem from 1872:

C'était un enfant, dix-sept ans à peine,

De beaux cheveux blonds et de grands yeux bleus.

De joie et d'amour sa vie était pleine,

Il ne connaissait ni le mal ni la haine;

Bien aimé de tous et partout heureux.

C'était un enfant, dix-sept ans à peine

De beaux cheveux blonds et de grands yeux bleus.

Much like Zola's Zéphirin, who possesses "une tête d'ange blond et frisé" (20: 24), the angelic form so lovingly described in Paul Déroulède's "Le Turco," from his first collection of Chants $d u$ soldat, will inevitably end up stretched out dead, "frappé d'une balle" (24). Such images may seem banal, but the particular, and particularly troubling, character of Déroulède's tender stanza resides in the violence of the appeal it justifies, succinctly expressed in the final words of the collection: "Que [. . . / La France et les Français n'aient qu'un seul but : détruire / La Prusse et les Prussiens !" (127). Near-genocidal revanchiste fantasies such as this are a far cry, of course, from the meliorist politics of Sand, yet those fantasies are arguably just as entitled as she is to speak with a sentimental voice. For the sentimental, lest we forget, is far from necessarily progressive. If anything, Sand was the aberration: as Zeev Sternhell has extensively documented, the instinctual, primordial stirrings of the sentiments had formed the beating heart of the antirationalist and especially the nationalistic discourses of the counter-Enlightenment since the mid-eighteenth century (discourses that Sternhell associates with figures as diverse as Herder, Vico, Burke, and Carlyle, to which names we might add that of Pierre-Simon Ballanche, author in 1801 of the counterrevolutionary Du sentiment; 264-90).

So while the fin de siècle conflict between such conservative, traditionalist, or counter-Enlightenment ideas and the bourgeois progressivism represented by Zola is well known, Vérité's sentimental narrative may also be seen to participate in a related but less readily appreciable political struggle: the struggle for the sentimental itself. It is the monopoly held by what might broadly be termed "right-wing" forces, and notably clerical ones, over notions of affect and sentiment, what the narrator calls "cette simple exploitation de la sentimentalité pieuse" (20:164), that Zola's novel sets out to challenge, principally by asserting-for indeed, it is little more than an assertion - that reason and sentiment are not after all mutually exclusive. "Je ne sais pas de raison plus solide, de cœur plus tendre," observes Marc of Simon in the first chapter (20:23), setting the pattern for the paradoxical insistence on the 
complementarity of the protagonists' rational and affective capacities that will recur at turning points in the plot. Yet despite the novel's repeated insistence on the merits of rationalism in the face of Catholic dogma, the idealism of Vérité somewhat undermines those claims. As Henri Mitterand observes, Vérité represents a "rupture [. . . ] avec l'objectivité du roman naturaliste, pour laisser une pleine expansion à un discours des valeurs où se laissent entendre les passions et les convictions de l'auteur" (93). This departure from the Flaubertian "objectivity" - always in some sense an illusion, but an extremely powerful one-of Les Rougon-Macquart exposes the ideological preferences of Zola's later fiction in a way that makes obvious their a priori character, a fundamental characteristic of the roman à thèse (Suleiman 4, 7). More troublingly, however, Zola's utopian heroes utter words whose very meaning appears to be dependent on our acceptance of, or our refusal to accept, the political beliefs they profess. The result is something of a rhetorical impasse from which nothing emerges so much as the sense that Zola's liberalism is itself a new bigotry; as Jeffrey Mehlman has observed, the novelist's attack on Catholicism in Vérité "is so unrelenting as to figure as no more than the flipside of his adversaries' anti-Semitism" (246).

Now it should be noted that there are moments in the novel when the author himself seems concerned to explore this impasse and its consequences; the untrustworthiness of political buzzwords, their tendency to take on different meanings in different mouths, becomes a topic of explicit-that is, presumably not unconscious-attention in the novel's critical central portion. In the course of a furious argument between Marc and his Catholic wife Geneviève, in which the latter denounces her husband's irreligion and confesses that she believes Simon to be guilty, the couple recognizes just this problem, agreeing on the impossibility of agreement. "Nous ne pouvons plus nous entendre," Geneviève complains, and Marc echoes: "C'est vrai, [. . .] nous ne pouvons plus nous entendre. Les mots n'ont plus la même signification pour nous, et tout ce que je te reproche, tu me le reproches" (20: 167). More pertinent, however, are the precise words whose meaning has become thus contentious for the pair. "J'aurais dû t'apprendre où sont la vérité et la justice," Marc laments, sententiously, to which Geneviève ripostes: "C'est moi qui sais où sont la vérité et la justice. Tu n'as pas le droit de prononcer ces mots-là" (20: 167-68). Now the phrase "Truth and Justice" has, of course, talismanic status in Zola's later writing, and especially in the projected tetralogy to whose final volumes it gave their titles (though Justice was never written). And yet the acknowledgment here that the phrase might be subject to widely divergent interpretations must appear almost fatal to Zola's political project, which depends for its rhetorical power on the supposed unanswerability of such concepts as he himself employs them. The significance of the problem may be apprehended if we consider that the set phrase "vérité et justice," that leitmotiv 
of Vérité, appears twice, and its component parts dozens of times, in Leo XIII's 1885 encyclical Immortale Dei, an important anticipation of his subsequent Rerum novarum (1891) and thus of the policy of ralliement. For the Holy Father to demand that the Catholic party participate in and influence secular state institutions "au profit de la vérité et de la justice" $(2: 49)$ is indisputably his prerogative, since these terms, far from being rationalism's inventions, are established theological principles. Zola's dismissal of Leo XIII's interventions as mere "opportunisme" (in Le Figaro of 1 December 1895) thus addressed a geopolitical question while skirting a thornier conceptual aporia whose resurgence in the novel of 1903 is visible not only in these moments of definitional dispute between the fictional spouses but also in Zola's decision to appropriate the Christian concept of the évangile to describe his valedictory series. That choice is perhaps attributable to the confident posturing of a secularist with a bullish legislative majority on his side, but it is also a risky strategy: such borrowings can only exacerbate the terminological difficulties encountered by the characters, further blurring the supposedly bright line between one ideology and its abject other.

Moreover, even if Zola sometimes seems concerned to thematize these ambiguities explicitly in the arguments between Geneviève and Marc, it is difficult to resist the conclusion that they are more widespread, more insistent, and more disruptive of the thesis of this roman à thèse than the novelist himself allows. Mehlman notes how "the very language of the novel" seems "intent on underscoring, against the author's own argument, a perilous symmetry" in the curious similarity between the name of Zola's protagonist, "Simon," and the crime- "simony"-of his venal Catholic enemies; the novel thus pits the "simonistes" against the "simoniaques" (246). An even more pervasive, and arguably more disturbing, example of this kind of instability is to be found, again at the heart of the narrator's own discourse, in the vicissitudes of the adjective délicieux and its derivatives. This word, as we saw at the beginning, encapsulates the delight of the Dreyfus family's reunion following Alfred's pardon, that "minute délicieuse," and similarly functions in Vérité as a leitmotiv connoting the pleasures of family life, as when the Simon and Froment households, now united by marriage, enjoy "[un] dinêr [. . .] d'une gaîté délicieuse" (20:362). More specifically, the word is deployed with particular frequency as an attribute of children; we have already seen it applied, for example, to Georgette, the "fillette délicieuse" of Marc's former pupil (20: 351); it is similarly used in reference to Simon's children, "des enfants délicieux" (20:91), and to his great-granddaughter Rose, a "chère et délicieuse créature" as a babe-in-arms and a "délicieuse fillette" some years later, in a subsequent chapter (20:372, 378). Shortly before, Marc takes in his arms a young boy from the town who has come to witness Simon's return: the child is "ému jusqu'aux larmes," while Marc is "délicieusement touché" (20: 364). 
Perhaps most importantly, this touching quality is attributed to little Zéphirin: "cette tête, malgré sa pâleur bleuie, gardait son charme délicieux, une tête d'ange blond et frisé, un visage délicat de fille" (20:24). In these examples, the notion of the délicieux appears to be employed to evoke the innocent appeal of the child as a moral quality, though as the example of Zéphirin makes particularly clear, the word has obvious physical implications as well. The children so labeled are, the reader must assume, at the very least aesthetically pleasing-put simply, they are cute.

But consider another occurrence of the same word, the first in the novel, in which Marc's marriage to Geneviève is attributed to the good offices of his friend and mentor Salvan, "que l'amour délicieux des deux jeunes gens attendrissait" (20:21). Lest the reader seek to understand Marc and Geneviève's "amour délicieux" in narrowly romantic (that is, perhaps, quasi-fraternal) terms, the narrator will go on to insist elsewhere upon its intense and transformative erotic dimension; sure enough, when Salvan refers sometime later to "cette Geneviève délicieuse que vous adorez," Marc's frank response is to agree that she is "si aimante, si ravie dans mes bras" (20:104). In these moments concerning Geneviève, then, "deliciousness" is clearly related to sexual appeal, as would also seem to be the case when the description of the minor character Charlotte as "délicieuse" is justified by the narrator's observation that she is "libérée des pruderies mensongères" (20:360)—which we understand to mean sexually liberated to the precise degree that Zola deems healthy for women. This erotic freighting of the notion of the délicieux is made most explicit, finally, in relation to Catholicism. In a passage concerning Geneviève's relapse into religiosity, the troubled young woman recalls her first communion and thinks fondly of "le doux Jésus qu'elle choisissait si délicieusement pour fiancé" and of "l'amour divin dont elle jurait [. . . de ne plus goûter les délices" (20: 201). It is a running obsession of this anti-Catholic novel, one borrowed from Jules Michelet's Du prêtre, de la femme, de la famille (1845) and essentially repeated unchanged by Zola, that women's experience of the Catholic mysteries is an erotic one, the perverse redirection of sexual energies more properly reserved for the pleasures of the marital bed. We know, for instance, that Geneviève's bigoted grandmother Mme Duparque turned to the Church because her loveless marriage stifled her "besoin de sensualité" and thus obliged her to seek in religious observance what the narrator describes in obviously orgasmic terms as "un délicieux frisson" (20:291).

So the word délicieux, which even by Zolian standards occurs with bizarre frequency in Vérité, must surely emerge from such double service as something of a lexical liability. Given its-at least-dual significance, how are we to distinguish one form of deliciousness from another: childish appeal from adult allure, the cute from the sexy, the touching from what we may touch? The pathological inability to make those distinctions belongs, of course, to 
the novel's figure of sexual monstrosity, the vile pederast Frère Gorgias, who in a final, histrionic confession to the townspeople of Maillebois (assembled to witness the return of the exonerated Simon) makes the by-now inevitable exclamation: "Ô mon Dieu ! vous avez fait l'enfant si délicieux, avec sa tête blonde et frisée de petit ange" (20:368). We may of course take this as a repellent hypocrisy, a perverse and self-serving blurring of two meanings that are intuitively separate. And yet it is intriguing that Zola should not only put in Gorgias's mouth the very words employed earlier by the narrator (who described Zéphirin's "tête d'ange blond et frisé"), but also arrange those words here rather than there into one of those double-prepositional constructions"avec sa tête blonde et frisée de petit ange"-that are an unmistakable feature of Zola's own narrative voice. There is, it seems, a troubling conformity between the narratorial and the pederastic gaze when either falls, as both do so obsessively fall, upon the body of the beautiful child. What the narrator considers salient in Zéphirin, Gorgias also considers salient; what the former finds aesthetically appealing appeals in equal measure to the latter. The very characteristics that the one presents as demanding our sympathy for the victim are advanced by the other as motivating-if not excusing-his crime.

\section{Killing Naturalism}

This, of course, is a symmetry that the novel can only disavow, and it is not alone in doing so. It is to precisely this kind of confusion, indeed, that James $R$. Kincaid alludes when, in a study of the modern Western obsession with child abuse, he notes that "we have made children lovable, which is fine, but we have also failed to make it clear to ourselves just what that means" (14). The culture that fetishizes innocence, Kincaid suggests, soon finds itself ensnared in an impossible double bind, irresistibly drawn to what is most emphatically forbidden. Kincaid locates the cultural shifts that produced this imbroglio in the early nineteenth century, and specifically with Romanticism, yet one might argue that Zola's new sentimentalist erotics is more vulnerable to these giddy ambiguities than any other. For it is, after all, Zola's particular idea of the erotic that mandates the ever-closer rapprochement of sex and children, making the lavishly described and always irreducibly physical charms of those "enfants délicieux" the motive force of sexual desire, spectrally present wherever the act itself is evoked or even, one supposes, performed. The recurrence of the word "délicieux," that troublesome double-entendre, appears in this light as the return of the repressed in the most classically Freudian sense, that is to say, the ineluctable insistence within the novel's conscious discourse of the very element that is most disruptive of it.

What stabilizes this confusion, however illusorily, or rather, what permits its ultimate disavowal, is the spectacular and yet overwhelmingly stereotypical 
nature of the deviance of Frère Gorgias. The pedophile monk acts as a sort of ideological sponge, soaking up the excess of meaning that overflows from each of these teary and tender encounters between the beautiful child and the desiring narrator, encapsulating within himself all the novel's deviant desire and thus allowing its ideological recuperation. Firstly, as a nonreproductive body, Gorgias is already persona non grata to the right-thinking, natalist Republicanism of fin de siècle France-and an audacious, logical sleight-of-hand suffices to transform those who do not want children into those who want them all too much, by making child-rape the logical extremity of the anti-child attitude apparently manifested by a failure to reproduce. More specifically, however, the meaning of Gorgias as a clergyman, unlike that of the delicious childish body, is legible to all by the light of a great many august antecedents: Zola's monk clearly recalls the clerical hypocrites, lechers, and rapists of the Heptaméron, of Le Tartuffe, of La Religieuse, of Revolutionary propaganda, of Restoration subversion, of Paul Bonnetain's Charlot s'amuse (1883), and of Octave Mirbeau's Sébastien Roch (1890), in short, of the long and febrile tradition of French anticlericalism, looming larger in the first years of the twentieth century than it had for some time.

It is, we must assume, at least partly in acknowledgment of this tradition that Marc, in one of the novel's more breathtakingly ideological moments, offers in free indirect discourse the following neat assessment of the rape and murder of Zéphirin: "Enfin, le viol et l'assassinat étaient comme signés, un sadisme cruel et sournois, un mélange d'ignominie et de religiosité, qui décelaient le froc" (20:82). In a novel whose central episode is a miscarriage of justice based on the misreading of an ambiguous monogram (the paraphe on the writing sample found in Zéphirin's mouth, standing in for the bordereau of the Dreyfus Affair), such a confident appeal to the unproblematic legibility of any signature-let alone a metaphorical one-is either cunningly ironic or weirdly unguarded. The confidence with which this association is made seems momentarily to recall the old hermeneutic certainty of Naturalism, its unflinching eagerness to identify, describe, and display pathology of all kinds. Indeed, we might go further and remark that Gorgias is the only "Naturalist" character in Vérité: a figure of spectacular deviance among a cast of characters whose life's work is to ensure conformity (i.e., teachers) but, crucially, one who is himself in conformity with a preexisting literary typology (the pervert priest) where the others are unprecedented, utopian "new people." Indeed, in the same scene that he employs that Zolian construction ("avec sa tête blonde et frisée de petit ange"), Gorgias also performs an extreme version of the great Naturalist fantasy, announced ten years earlier in Le Docteur Pascal (1893): the famous "tout dire" $(15: 430)$. "Écoutez-moi," he shrieks to the astonished people of Maillebois, "je veux tout vous dire!" (20:365). He goes on in grand Naturalist style to pursue what the narrator calls his "récit" "sans taire aucun 
détail" (20: 369); though it seems equally pertinent to note that what he refuses to silence are his "appétits énormes," as well as the "détails sordides, féroces" of his crime (20:367,369)-that is, the precise sort of subject matter characteristic of Naturalism's own shocking narrative expansiveness. Much like the Zola of L'Assommoir or La Terre, we might say, "il dit tout en termes crus" (20:368). In these episodes, then, the pervert and the literary techniques needed to narrate perversion emerge as inextricably linked; indeed, the passage almost reads as a symbolic endorsement of the claim, advanced in 1887 by the pugnacious authors of the infamous "Manifeste des Cinq," that the very desire to narrate the horrors of La Terre was indicative of its author's underlying, probably sexual, abnormality-an abnormality they described, tellingly for our purposes, as "des manies de moine solitaire" (Bonnetain 1). Certainly, Gorgias's confession as presented here finds no protection in, and therefore seems rather like a recantation of, Zola's earlier understanding of tout dire as an ethical and therapeutic imperative ("tout dire, pour tout guérir," as the claim ran). Rather, the narrative that Gorgias insists on supplying appears excessive, obscene, an unwelcome intrusion within the idyll of sentimental harmony-manifested principally in tears and embraces and thus broadly nonlinguistic-that greets Simon's return.

Now, as peculiar as this pathologization of the narrative impulse might appear in Zola, it is, I suggest, anticipated by a couple of moments in his Dreyfus journalism. In his excoriating open letter to President Félix Faure, published in L'Aurore on 13 January 1898, Zola reserved particular animus for Major (later Lieutenant Colonel) Armand Mercier Du Paty de Clam, the "homme néfaste," in Zola's words, who oversaw the initial framing of Dreyfus (18: 438). The terms in which Zola couches his accusations regarding this particular officer are intriguing:

[Du Paty de Clam] apparaît comme l'esprit le plus fumeux, le plus compliqué, hanté d'intrigues romanesques, se complaisant aux moyens des romans-feuilletons, les papiers volés, les lettres anonymes, les rendez-vous dans les endroits déserts [...]. (18: 438)

Je ne puis m'empêcher de retrouver là le lieutenant-colonel du Paty de Clam, en reconnaissant les expédients de son imagination fertile. Son œuvre, la culpabilité de Dreyfus, était en péril [. . .]. La révision du procès, mais c'était l'écroulement du roman-feuilleton si extravagant, si tragique, dont le dénouement abominable a lieu à l'île du Diable ! (18: 441)

Perhaps we would be ill advised to attach too much significance to what may be throwaway metaphors. And yet in figuring the architect of Dreyfus's ordeal 
not as a novelistic villain but as a novelist, these passages seem to announce a new suspicion of the literary imagination, which now emerges as a kind of psychological disturbance in itself. Such an idea was, once again, not a new one. "Fumeux," "hanté," "extravagant": this is the language not only of the "Manifeste des Cinq" but also of Max Nordau's extended character assassination of Zola and his art in Degeneration (1892), which indicted the novelist's "instinctive inclination to depict demented persons" and his "coprolalia" (499). "His consciousness is peopled with images of unnatural vice," Nordau insisted, concluding finally that Zola was "a high-class degenerate" (500), by which one might almost imagine he meant a sort of "meta-degenerate": a speaker of degenerate things.

If, as these quotations from "J'accuse !" and the example of Gorgias suggest, Zola himself had eventually come to share this apparently philistine view, or at least a version of it, we can probably agree with Laville that the Dreyfus Affair played a part in the conversion (234-35). Clearly, the Affair crystallized a number of preexisting connections between the Catholic elite, antirationalism, anti-Semitism and anti-Republicanism, and a certain literary milieu noted for its particular imaginative faculties, as embodied in Huysmans and Rachilde. Did Zola suddenly realize, in those politically charged months leading up to 1898 , that when the monstrous heroine of Rachilde's La Marquise de Sade (1887) could be an avid consumer of Naturalist novels (285), Naturalism and its Decadent other were no longer as clearly distinct as present political circumstances made desirable? Perhaps. Yet in a sense, what made the thematic overlap between Zola's Naturalist fiction and the literature of Decadence so troublesome was, more broadly, their shared, persistent nonprescriptivity, their constant refusal to provide a "moral" that might explain how the preceding images ought to be understood-the Naturalist novelist, as Zola put it in 1880 , being "un greffier, qui se défend de juger et de conclure" (9:378). Now Vérité most certainly does have a moral: the penultimate sentence, "il n'est de justice que dans la vérité, il n'est de bonheur que dans la justice" (20: 392), an idea the narrator offers as somehow conclusive but which all but the most quiescent of readers will surely find raises more questions than it answers. In advancing this moral, whatever its shortcomings, Zola takes advantage of what we might call the prescriptive privilege of the idealist novelist, and it is in this regard that the "fourth" Zola continues to differ from Nordau. For while Nordau denounces the early Zola's hypocrisy in "ridicul[ing] the 'idealists' as being narrators [. . .] of "what never happened" (495), on the grounds that Zola's literary procedure is equally fanciful and therefore equally deserving of contempt, the Zola of 1899 considered the idealist imagination not only permissible (as fundamentally different from the corrupt DecadentNaturalist vision) but even profoundly necessary-while the letter to Mirbeau self-deprecatingly attributed the desire to "rêver un peu" to the effect of age, it 
is clear that the Dreyfus Affair had made Zola believe, as George Sand before him, in the enhanced political purchase of an idealizing, prescriptive fictional aesthetics.

The cost of this increased power, of course, is the sacrifice of Zola's earlier writing: its characters, its topoi, its narrative modes, its historicity. Zola must, in Huysmans's phrase, "jou[er] [. . . ] le rôle du bon Sicambre" and burn what he has adored (71). This aesthetic infanticide is simultaneously displayed and dissimulated in Vérité by means of a phantasmatically convenient disappearance: the embarrassing Gorgias, who in the novel's long final episode already seems "un revenant du passé" (20:365), will die not at the hands of the Maillebois crowd-now far too enlightened to resort to violence, however strong the temptation (20:369)-but as the natural consequence of his own corruption. Soon after delivering himself of his final harangue, Gorgias is found murdered and, as the narrator coyly puts it, "souillé" in the vicinity of a certain "maison louche" (20:374; another dangerous symmetry-this previously unmentioned "maison" appears in the narrative just as Simon takes possession of his unifying "maison votive"; 20: 362), his demise in this manner notified to the reader in a couple of terse lines. At the level of story, his death in the gutter very obviously symbolizes the final suppression of those "abominations de la rue," which, in the letter to Mme Dreyfus, so conveniently "meurent au seuil domestique" (18: 466) be it Dreyfus's or that of Simon's new home; it thus connotes the deletion of whatever residual deviance might trouble the unanimity of Maillebois's "baiser général." But in Gorgias's death, more importantly, Naturalism itself dies in effigy, its form and content finally consumed by the entropic tendencies that determined its success. The literature of historical deviance-namely, Zola's "natural and social history of the Second Empire"-makes way for the "healthy" literature of the future.

\section{Conclusion: "Naturalisme, pas mort !"}

That political circumstances toward the end of Zola's life, and essentially the struggles of the Dreyfus period, demanded such an aesthetic change is a relatively unproblematic literary-historical observation. Yet this does not explain away the properly aesthetic problem posed to literary critics by the Quatre Évangiles. In an important recent monograph, Susan Harrow (following some remarks of Henri Mitterand) notes "the urgency of prising Zola out of the nineteenth century and of probing the potential connections between Naturalism and the broad, hybrid seam of twentieth-century experimentalism," imagining a new, "proto-modernist" Zola as yet underexplored by critics (1). Now, such a rediscovery is of undeniably paramount importance if the gradual liberation of Zola's canonical fiction from reductive critical frameworks is to continue. And yet Harrow's invocation of this new "prospective" 
Zola, one who looks forward to twentieth-century avant-garde literary practice, draws our attention to a paradox. For it is the very novels in which Zola is at his most self-consciously forward-looking, and which abandon, in Mitterand's words, "la vision historique, pour jouer avec les ressources d'un imaginaire du futur" (93), that prove least amenable to aesthetically prospective readings. Romans à thèse and thus, in Suleiman's words, "antimodern" (18), they are placed decisively beyond the pale of "serious" experimentalist literature by their deliberate adoption of sentimental modes. "The sentimental as the insincere, the manipulative, the vicarious, the morbid, the knowing, the kitschy, the arch," as Sedgwick put it (143): the discrediting of such writing in these terms, already begun by Flaubertian realism, would only be amplified by the pioneers of early twentieth-century modernism. Yet if anything, it was this instance of "late style," this last sentimental turn, that constituted the wildest literary experiment-what Laville calls the "audace" (243)—of the author of Le Roman expérimental. We need only consult our own bookshelves to confirm that the experiment was not altogether successful; still, any attempt to appreciate afresh the modernity of Zola's writing must, we might argue, first come to terms with the novelist's own recalcitrant understanding of just what the literary future held.

And yet, perhaps this is an unreasonable challenge given the instability of Zola's final, futuristic narrative. The inherent ambiguities of the novel's own sentimental-erotic politics can only be overlooked, as we have seen, thanks to the presence of a stabilizing figure of Naturalist deviance, Frère Gorgias; and yet, more importantly, the novel's ultimate, triumphalist celebration of his (and thus of Naturalism's) demise is itself marked by uncertainty. Naturalism, as Zola knew well, had been pronounced dead many times before 1903 (and often by the selfsame cultural forces Zola set out to combat in Vérité). Its constant resuscitation, announced inter alia in 1891 by Paul Alexis in his exclamation "Naturalisme, pas mort !", continued throughout Zola's lifetime, and its many afterlives are to be found not only in the modernist resonances revealed by Harrow but also in the seemingly limitless adaptations Naturalist texts have gone on to know (Griffiths 1-10). In this light, the narrator's description of Gorgias as "un revenant du passé" must appear less effective as a means of circumscribing his influence. It is, after all, in the very nature of revenants to come back-and probably more than once (cf. Chaitin 197). Perhaps Zola sensed this and chose his word accordingly. Yet one wonders whether he guessed that both the "deviance" and the interest in deviance that he conjoined in this ghostly figure would not simply haunt his tender City of the Future, but outlive it. 


\section{Works Cited}

Bonnetain, Paul, J.-H. Rosny, Lucien Descaves, Paul Margueritte, and Gustave Guiches. "La Terre : à Émile Zola." Le Figaro 18 Aug. 1887: 1.

Chaitin, Gilbert. "Le Cauchemar de (la) Vérité, ou le rêve du revenant." Les Cahiers Naturalistes 82 (2008): 187-97.

Cohen, Margaret. The Sentimental Education of the Novel. Princeton: Princeton UP, 1999.

Déroulède, Paul. Chants $d u$ soldat, Nouveaux Chants du soldat. Paris: Calmann Lévy, 1881.

Donzelot, Jacques. La Police des familles. Paris: Minuit, 1977.

Griffiths, Kate. Emile Zola and the Artistry of Adaptation. Oxford: Legenda, 2009.

Harrow, Susan. Zola, The Body Modern: Pressures and Prospects of Representation. Oxford: Legenda, 2010.

Huysmans, Joris-Karl. À rebours. Paris: Gallimard, 1977.

Kincaid, James R. Erotic Innocence: The Culture of Child Molesting. Durham: Duke UP, 1998.

Laville, Béatrice. "L'Écriture de l'utopie." Zola à l'œuvre : Hommage à Auguste Dezalay. Ed. Gisèle Séginger. Strasbourg: Presses universitaires de Strasbourg, 2003. 233-44.

Leo XIII. Immortale Dei, encyclical letter on the Christian constitution of States (1885). Lettres apostoliques de S.S. Léon XIII, encycliques, brefs etc. 7 vols. Paris: Roger and Chernovix, 1893-1904. 16-53.

Mehlman, Jeffrey. "Zola's Novel of the Dreyfus Affair: Between Mystique and Politique." Jews, Catholics, and the Burden of History: Studies in Contemporary Jewry 21. Ed. Eli Lederhendler. Oxford: Oxford UP, 2005. 243-51.

Mitterand, Henri. “Le Quatrième Zola.” Euvres et critiques 16.2 (1991): 85-98.

Nordau, Max. Degeneration. Ed. George L. Mosse. Lincoln: U of Nebraska P, 1993.

Rachilde. La Marquise de Sade. Paris: Mercure de France, 1987.

Schafer, Sylvia. Children in Moral Danger and the Problem of Government in Third Republic France. Princeton: Princeton UP, 1997.

Schor, Naomi. George Sand and Idealism. New York: Columbia UP, 1993.

Sedgwick, Eve Kosofsky. Epistemology of the Closet. Berkeley: U of California P, 1990; repr. 2008.

Sternhell, Zeev. Les Anti-Lumières : Une tradition du XvIII siècle à la guerre froide. Rev. ed. Paris: Gallimard, 2010. 
Suleiman, Susan. Authoritarian Fictions: The Ideological Novel as a Literary Genre. New York: Columbia UP, 1983.

White, Claire. "Labour of Love: George Sand's La Ville noire and Émile Zola's Travail." MLR 106 (2011): 697-708.

Zola, Émile. CEuvres complètes. 21 vols. Paris: Nouveau Monde, 2002-9. 
Copyright of Romanic Review is the property of Columbia University, Department of French \& Romance Philosophy and its content may not be copied or emailed to multiple sites or posted to a listserv without the copyright holder's express written permission. However, users may print, download, or email articles for individual use. 